Language in Africa 1(3), 2020, 216-243. doi: 10.37892/2686-8946-2020-1-3-216-243

\title{
THE NUMERAL SYSTEM IN LONGUDA
}

\author{
Friederike Vigeland \\ Johannes Gutenberg University Mainz \\ fvigelan@uni-mainz.de
}

\begin{abstract}
This article gives an overview of the cardinal and ordinal numerals in Longuda, a language cluster in north-eastern Nigeria, belonging to the Adamawa branch of the Niger-Congo languages. It focuses on three of its five varieties, namely Deele, Guyuk and Gwaanda, analysing the morphology of the numerals, their behaviour in a noun phrase and the derivation of ordinal numerals from cardinal numerals. It becomes clear that numerals in Longuda are neither adjectives nor nouns but should rather be analysed as being on a scale in-between those lexical categories. The tendency in the languages of the world that lower ordinal numerals are suppletive forms while higher ones are regularly derived from cardinal numerals applies to Longuda as well. At the end of the article, the findings of Longuda numerals are compared to other Adamawa languages and the Niger-Congo family as a whole as compiled by Boyd (1989) and Pozdniakov (2018).
\end{abstract}

Key words: cardinal numerals, ordinal numerals, Longuda, Adamawa, noun phrase, agreement

\section{Introduction}

Longuda, also known as Nungurama, is a language cluster of five dialects or varieties, namely Cerin, Deele, Guyuk, Gwaanda and Kola (Kleinewillinghöfer 1996, Sabe 2014). The Longuda cluster is generally classified as a separate group within the Adamawa languages (e.g. in Kleinewillinghöfer (2020: 223); as group 10 in Greenberg (1963: 9) and subgroup V in Blench (2013)). It is spoken in the north-east of Nigeria, mainly in Adamawa State but also in Gombe State.

As can be seen in the examples (1a) to (1c), a noun phrase in Longuda typically starts with the head noun and is followed by its attributes which is characteristic for Adamawa languages and most Sub-Saharan languages in general (Dryer 2013; Kleinewillinghöfer 
2020: 226). It should be noted that example (1c) is an elicited sentence and would rarely occur in spontaneous speech ${ }^{1}$.

(1) a. Deele

bālî́ fár-hâ nā-hà-kwấ

cow.CL4 red-CL4 NUM-CL4-two

'two red cows'

b. Guyuk

$z \bar{c}-t \bar{a} \quad$ ná- $\emptyset$-sìr $\quad$ tá-mà

snake-CL8 NUM-CL8-two CL8-DEM

'those two snakes (out of sight)'

c. Guyuk

$d z w a ́-b \quad$ sīnì-b nà-b-sìr bī-mà nì-bè

child-CL2 tall-CL2 NUM-CL2-two CL2-DEM POSS-CL2

'those two tall children are mine' (lit. 'those my two tall children')

Besides showing the order of attributes in a noun phrase, the sentences above also give an insight into the fully developed noun class system with overt class marking on the noun as well as agreement on (most of) the attributes in a noun phrase. The noun classes are suffixed to the noun stem. Sometimes, they are shortened (1c) or even deleted (1a). ${ }^{2}$ Adjectives and possessive pronouns agree with the noun by means of a suffix whereas demonstrative pronouns make use of an agreement prefix. Numerals show a more divers picture as will be demonstrated in the upcoming chapters.

${ }^{1}$ Examples without an indication of a source are my own.

${ }^{2}$ Elstermann, Fiedler \& Güldemann (2019) take a different approach to this phenomenon. They propose that the "A-form [noun class affix of the shape CV] is derived from the T-form [noun class affix without the final vowel] by adding a final element - $a$ " (Elstermann et. al 2019: 6). According to their data, the A-form is used as a citation form as well as in combination with the definite marker whereas the T-form is used in a noun phrase with an adjective. My data does not support this view entirely. Since this article is not primarily concerned with short and long noun class suffixes, it will not be discussed here any further. 
An outline of the class system is presented in Table 1. It shows the noun suffixes although agreement affixes coincide with them (with the exception of class 6 which in some cases has an agreement marker $\tilde{\imath}$ (not relevant for this article)). ${ }^{3}$ In this article, I number the noun classes as well as their agreement affixes consecutively for the sake of convenience and for easier comprehensibility (capital letter A stands for either $-a$ or $-\partial /-e$ depending on the advanced tongue root feature of the vowels of the respective lexeme).

Table 1

\section{Outline of the noun class system in Longuda:}

noun affixes

\begin{tabular}{cc|cc}
\hline \multicolumn{2}{c|}{ singular } & \multicolumn{2}{c}{ plural } \\
\hline CL1 & $-y A$ & CL2 & $-b A$ \\
CL3 & $-w A$ & CL4 & $-h A$ \\
CL5 & $-l A$ & CL6 & $-A$ \\
CL7 & $-k A$ & CL8 & $-t A$ \\
& CL9 & $-m A$ & \\
\hline
\end{tabular}

Numerals in the world's languages can be divided into two groups "with different functional domains" (Stolz \& Veselinova 2013). Cardinal numerals are used to specify nouns by being attributes of a noun in

${ }^{3}$ Güldemann \& Fiedler (2019) reappraise the "traditional" view on gender systems in Niger-Congo languages. They criticize "a consistent alliterative oneto-one mapping of agreement and nominal form classes conflated under the philological concept of "noun class" (Güldemann \& Fiedler 2019: 95) and propose a new methodological approach with the four concepts agreement class, gender, nominal form class and deriflection (ibid.: 97). Relating it to Longuda, the agreement class would entail the affixes of attributes in a noun phrase with "identical behaviour across all agreement contexts" (ibid.: 98) whereas the markers on the nouns with "identical properties in morphophonological form" (Elstermann et. al 2019: 2) form a nominal form class. This approach in regard to Longuda will be discussed in detail elsewhere but will not be subject of this present article. 
a noun phrase while ordinal numerals "typically identify the position a given member of a set occupies relative to other members of the same set" (ibid.). In most languages, they are derived from cardinal numerals, sometimes the lower ordinal numerals have suppletive forms (Dryer 2007: 164).

This article gives an overview on cardinal and ordinal numerals in Longuda which not only show dialectal differences but are morphologically exceptional in comparison to other Adamawa languages. The focus will be on three of the five Longuda varieties, namely Deele, Guyuk and Gwaanda. For the other two varieties Kola and Cerin little more than the numerals from 'one' to 'hundred' are known therefore they will only be discussed in the general overview in §2.1. In the following chapter, the structure of cardinal numerals and agreement strategies within a noun phrase will be discussed, compared to cross-linguistic tendencies and applied to universals formulated by Corbett (1978). Chapter 3 will show how ordinal numerals are derived from cardinal numerals and compare the results to a survey undertaken by Stolz \& Veselinova (2013). It will also explore how ordinal numerals agree with the head noun in a noun phrase. Finally, the Longuda numerals will be compared to those of other Adamawa languages and more generally to other Niger-Congo languages.

The data on Deele and Guyuk, if not otherwise indicated, was collected in Nigeria in March and April 2019 as well as January and February 2020. The Gwaanda data stems from unpublished texts, questionnaires and field notes collected by Ulrich Kleinewillinghöfer from 1990 to 1995 (indicated in square brackets after the examples) and myself in 2017 as well as from two published books on different aspects of Gwaanda (Hiraki 1986; Sabe 2014).

\section{Cardinal numerals}

The formation of cardinal numerals can differ significantly as Hurford (2001: 10758) states: 
"[...] most languages have simple numeral words for values up to 10 , and then resort to syntactic combinations. After 10, almost without exception in any language, the only values for which there are morphologically simple words are those used as multiplicative bases, such as 20 , $100,1,000$, and so on."

In addition to a range of simple and complex numerals the classification of numerals is often very divers. In many instances, numerals are classified with adjectives despite the many exceptions. Corbett (1978: 368) takes this into account and proposes a universal: "(1) simple cardinal numerals fall between adjectives and nouns". Borchardt (2011: 12) agrees: "Indeed, it is difficult to find any nonrestricted numeral system ${ }^{4}$ whose numerals behave completely alike throughout the whole system". She comes to the conclusion that numerals should therefore be treated as a distinct lexical category in grammar.

According to Corbett (1978: 368) there is a tendency for lower numerals to be more adjective-like while higher numerals are more noun-like as he suggests in his second universal regarding cardinal numerals: "(2) if they vary in behaviour it is the higher which will be more noun-like." Hurford (2001: 10757) specifies the universals by adding that the more adjective-like numerals are normally the first few numerals up to 'two', 'three' or 'four' whereas noun-like numerals are "especially those used as multiplicative bases, such as hundred and million" and "do not agree in gender with a head noun" (Hurford 1994: 38).

\subsection{Cardinal numerals in general counting}

In this chapter, the cardinal numerals as used in general counting will be discussed. There will be an overview on the numerals from 'one'

4 "Restricted numeral systems only have a limited set of numeral expressions and the end point $\mathrm{L}$ of the system is quite low in the number value" (Borchardt 2011: 11). 
to 'hundred' in all five varieties followed by a detailed description and analysis. An examination of the underlying structure of the cardinal numerals is crucial in order to understand their behaviour in a noun phrase with its agreement markers (§2.1 to §2.4) and to comprehend the derivations used to form ordinal numerals out of cardinal numerals (§3.1 to $\S 3.3)$.

The cardinal numerals employ a decimal system as is described in Comrie (2013). In Table 2 the numerals from 'one' to 'hundred' in all five varieties of Longuda are presented.

Table 2

\section{Cardinal numerals 1-100}

\begin{tabular}{|c|c|c|c|c|c|}
\hline & Kola & Deele & Gwaanda & Guyuk & Cerin \\
\hline ' 1 ' & laatwè & kālīwá & kàlílā & nàkà̀l & nā:kál \\
\hline ' 2 ' & naakwế & $n \bar{a}: k w \tilde{a}$ & nāitsír & nà:sìr & nā:sír \\
\hline 3 & naatsár & nā'sár & $n \bar{a}: k w \overline{\tilde{\imath}}$ & nà:kwāī & nāikwáí \\
\hline 4 ' & néénnyìr & nāinír & nāanír & nàinìr & nāanìr \\
\hline ‘ 5 ' & naanyó & nāinó & $n \bar{a} \bar{\eta} \bar{\jmath}$ & nà̀ñ & nāanú \\
\hline '6’ & tsaaton & sā:tān & nā:kánāa:kwĩ̀ & nàkànà̀kwài & nākánā:kwáí \\
\hline ' 7 ' & $\begin{array}{l}\text { ínéényìr } \\
\text { inaatsár }\end{array}$ & nínásír & nīrnā:kwĩ̀ & nìnà:kwāī & nīnāikwáí \\
\hline ' 8 ' & nyíitìn & nīttín & nītīin & nütīn & nítìn \\
\hline ‘ 9 ' & $\begin{array}{l}\text { énàànyś } \\
\text { inéényìr }\end{array}$ & únān̄̄ónā & nīrnā̄ñ̄ & nìnàȳ̄ō & nīnāinú \\
\hline
\end{tabular}

${ }^{5}$ All Kola examples from 11 to 100 , as well as Cerin examples 15, 20 and 100 come from Kleinewillinghöfer (2014a; unpublished wordlists), Cerin examples 11, 12 and 30 are cited from Newman \& Newman (1977: 18), Gwaanda examples from 11 to 100 originate from Sabe (2014). The cardinal numerals quoted from the different sources were adopted without changes and therefore differ in their spelling from the other numerals. The only exception is $c$ that replaces $c h$. 
End of Table 2

\begin{tabular}{|c|c|c|c|c|c|}
\hline & Kola & Deele & Gwaanda & Guyuk & Cerin \\
\hline ' 10 ’ & koo & kô & $k \bar{v} r$ & $n^{w} \hat{\jmath ̂ m} /$ gûm & $n^{w} \hat{\jmath} m$ / gôm \\
\hline ' 11 ' & $\begin{array}{l}\text { (koo) } \\
\text { ń cúbré } \\
\text { láàtwè }\end{array}$ & $\begin{array}{l}\text { kô yír } \\
\text { kālì̄wà }\end{array}$ & $\begin{array}{l}\text { kuwar yir } \\
\text { kalila }\end{array}$ & $\begin{array}{l}n^{w} \bar{\jmath} m \text { yīrù } \\
\text { nàskàl }\end{array}$ & $\begin{array}{l}\text { gim nyiru } \\
\text { nakal }\end{array}$ \\
\hline$' 12$ ' & $\begin{array}{l}\text { (koo) } \\
\text { ń cúbré } \\
\text { nàkwé }\end{array}$ & $\begin{array}{l}\text { kô yír } \\
n \bar{a}: k w \tilde{a}\end{array}$ & $\begin{array}{l}\text { kuwar yir } \\
\text { naatsar }\end{array}$ & $\begin{array}{l}n^{w} \bar{\jmath} m \text { yīrò } \\
\text { nàssìr }\end{array}$ & $\begin{array}{l}\text { gim nyiru } \\
\text { nasir }\end{array}$ \\
\hline$' 15$, & $\begin{array}{l}\text { (koo) } \\
\text { ń cúbré } \\
\text { nànyó }\end{array}$ & kô yír nāinź & $\begin{array}{l}\text { kuwar yir } \\
\text { naanywa }\end{array}$ & $\begin{array}{l}n^{w} \bar{\jmath} m \text { yīrù } \\
\text { nà:n̄̄o }\end{array}$ & $\begin{array}{l}\text { nyúrú } \\
\text { nàànyó }\end{array}$ \\
\hline '20' & kúnàkwéi & kútānātākwã & nanatsər & nātásìr & nááthishìr \\
\hline$' 30 ’$ & $\begin{array}{l}\text { kúú nàà } \\
\text { tsár }\end{array}$ & kútánàtàsàr & nanakwi & nàtàkwài & $n a t^{h} i k^{h} w a i$ \\
\hline ' 100 ’ & pùlòwé & kv̄lākàlīwà & kulakaliwa & pūlàwè & pùlòwé \\
\hline
\end{tabular}

Before discussing every numeral in turn, the recurring and therefore striking morpheme na:- should be mentioned. Numeral 'one' in Guyuk and Cerin as well as 'two' to 'five' in all dialects exhibit this initial na:-. Synchronically, it can be analysed as an initial numeral marker (NUM) which is then followed by the numeral root. Diachronically, it can be argued that it is the root of the word naka 'hand' (with -ka being the noun class marker) that used to form a compound with the numeral word, its meaning being ' $\mathrm{X}$ items of a hand', i.e. ' $\mathrm{X}$ fingers'. It would confirm the crosslinguistic observation for the use of 'hand' as becoming a general numeral marker or base for complex numerals, as was shown e.g. by Epps (2006) for the Amazonian Nadahup language family, by Boyd (1989) for the Adamawa languages or by Pozdniakov (2018) for other sub-groups of the Niger-Congo family. Another possible explanation is that this morpheme originates from the lexeme for 'thing' nìá (Guyuk) or náà (Deele). It would be in line with Möller 
Nwadigo's ${ }^{6}$ (p.c.) analysis of the morpheme $n \dot{t}$ - in Baa numerals that show structural similarities to Longuda (Chan 2020).

There are three different lexemes within the dialects for numeral 'one': laatwe, kaliwa/kalila and na:kal. It is interesting to note that all varieties but Kola use the same numeral root kal but form the lexeme differently. Guyuk and Cerin add the abovementioned numeral marker na:- while Deele and Gwaanda attach an epenthetic vowel and an agreement marker - $w a$ or -la. It seems that a few decades ago Deele speakers used kaliwa and kalila interchangeably while nowadays kaliwa is the only accepted form and is therefore lexicalised whereas Gwaanda established kalila.

The numerals 'two' to 'five' all add the numeral marker na:- to the numeral root. A curious phenomenon is shown with the numerals 'two' and 'three' which are swapped in certain varieties. 'This also has an impact on numerals 'six' and 'seven' as described below.

In Kola and Deele 'six' is a compound of numeral 'three' and -ton/-tan which exact meaning is not yet known but presumably has the notion of 'double' or 'twice'. The other three dialects use a morphologically more complex construction with the lexeme for 'hand' naka, the numeral marker and numeral 'three' which could be paraphrased as 'three of each hand'.

Numeral 'seven' is a complex numeral composed of 'four' and 'three' in all five varieties, even though the lexeme 'three' differs in the varieties due to the swapping of 'two' and 'three'.

A very consistent lexeme throughout all varieties is numeral 'eight'. The first syllable $n t$ - is probably the root of 'four' in which case -ttn should have the function of a reduplicator (see also explanation for 'six').

${ }^{6}$ Mirjam Möller Nwadigo is currently a Ph.D. fellow at the research unit "Langage, Langues et Cultures d'Afrique" at the CNRS in Paris. She works on the Adamawa language Baa in Nigeria.

${ }^{7}$ I do not have an explanation for this phenomenon for now. A hypothesis on which is the original order is presented in section 4 . 
Numeral 'nine' is a copulative compound of 'four' and 'five', though the order of the numerals differs in Kola and Deele from the other three varieties.

There are three different lexemes for numeral 'ten'. The forms of Kola, Deele and Gwaanda have an Adamawa origin, as will be shown below. The origin of nwom is unknown whereas gum is likely a borrowing from the Chadic language Dera (also called Kanakuru) gûm "ten', ${ }^{8}$ the language the Guyuk are in contact with in the "Gongola Basin" (Kraft 1981: 131).

All numerals above 'ten' are formed by regular morphological processes that differ in the varieties. Numerals 'eleven', 'twelve' etc. are a combination of 'ten' and the single numeral connected by a morpheme yur or yurv. Kola has a different strategy by adding the single numeral to (koo) ń cúbré where koo is facultative and can be dropped in fast speech (Kleinewillinghöfer p.c.). The origin of the expression ń cúbré is unknown.

The language varieties employ slightly different derivational methods for the decimal numerals 'twenty' to 'ninety'. They all take the single numerals 'two', 'three' etc. as a base and combine it with 'ten' and 'hand' or one of those. In Deele, kútā is a nominalisation of 'ten' using the noun class suffix -ta and nátà is the plural form of nákà 'hand'. Both realise their noun class suffix as -to in this phonological environment. Kola uses a similar strategy but leaves out the noun class suffixes. Gwaanda reduplicates the numeral marker $n a$ - and Guyuk uses the plural form nata with its phonological change to nata.

For numeral 'hundred', Kola, Guyuk and Cerin have an invariable lexeme that still shows a former noun class suffix (-we) which is now lexicalised. In Deele and Gwaanda 'hundred' is formed by nominalisations of 'ten' and 'one', its development being unclear since mathematically 'ten' and 'one' do not equal 'hundred'.

The structure of the numerals described above can be summarized as shown in Table 3 .

${ }^{8}$ So far gûm was only recorded in counting, not in noun phrases. 
$\frac{n}{0}$

$$
\begin{aligned}
& \text { (I) } \\
& \text { ( } \\
& \text { 를 }
\end{aligned}
$$

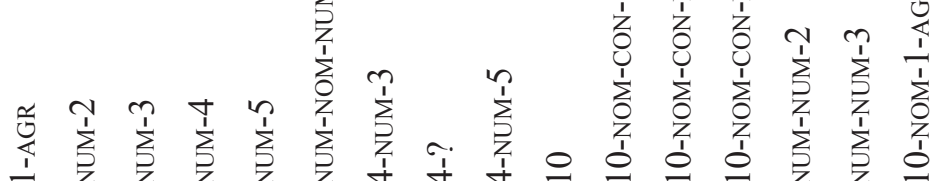

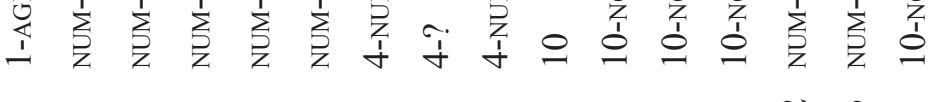

$$
\begin{aligned}
& \text { है }
\end{aligned}
$$




\subsection{Agreement on cardinal numerals in noun phrases}

As was shown before, attributes in a noun phrase generally follow the head noun and agree with its noun class through suffixes (adjectives, possessive pronouns) or prefixes (demonstrative pronouns). Cardinal numerals show a more divers pattern which will be discussed in the following subsections.

\subsubsection{Deele}

In Deele, numeral 'one' shows a suffixal agreement marker.

(2)

\begin{tabular}{|c|c|}
\hline $\begin{array}{l}\text { a. ná-k } \bar{\partial}^{9} \\
\text { hand-CL7 } \\
\text { 'one hand' }\end{array}$ & $\begin{array}{l}k a ́ l i \bar{l}-k \bar{a} \\
\text { one-CL }\end{array}$ \\
\hline $\begin{array}{l}\text { b. yír } \\
\text { man.CL1 }\end{array}$ & $\begin{array}{l}k \bar{a} l \bar{\imath}-y \bar{a} \\
\text { one-CL1 }\end{array}$ \\
\hline
\end{tabular}

Numerals 'two' to 'five' agree with the head noun through a prefix. Therefore, the numeral marker $n a-$ as well as the agreement marker precede the numeral root. ${ }^{10}$

${ }^{9}$ Vowels in all Longuda varieties are subject to the advanced tongue root (ATR) vowel harmony, affixes and clitics assimilate to the vowels of the head (Kleinewillinghöfer 1994; 1996). In fast speech, the final $-a$ of a lexeme or morpheme can be weakened to a schwa if another lexeme or morpheme is following, making it possible for a [+ATR] vowel (in this case [ə]) to enter a lexeme with [-ATR] vowels. The appearance of the schwa has become the lexicalised form in some expressions (see e.g. the cardinal numeral 'six' in Gwaanda, Guyuk and Cerin (\$2.1)).

${ }^{10}$ It is possible to analyse the agreement marker as a suffix of the numeral marker na-. However, as will be shown later on in this subsection, the numeral marker can be dropped under certain circumstances, leaving only the bare numeral word. This leads me to the analysis of the numeral word to be the root and both $n a-$ and the agreement marker as being prefixes of that root. 
$\begin{array}{cl}\text { (3) a. bālî́-há } & n a ́-h \bar{a}-k w a \tilde{a} \\ \text { cow-CL4 } & \text { NUM-CL4-two } \\ \text { 'two cows' } & \\ \text { b. yí-b } & \text { nā-b-já } \\ \text { man-CL2 } & \text { NUM-CL2-five } \\ \text { 'five men' } & \end{array}$

The numerals 'six' to 'ten' as well as 'twenty', 'thirty' up to 'hundred' are invariables hence agreement marking is absent.

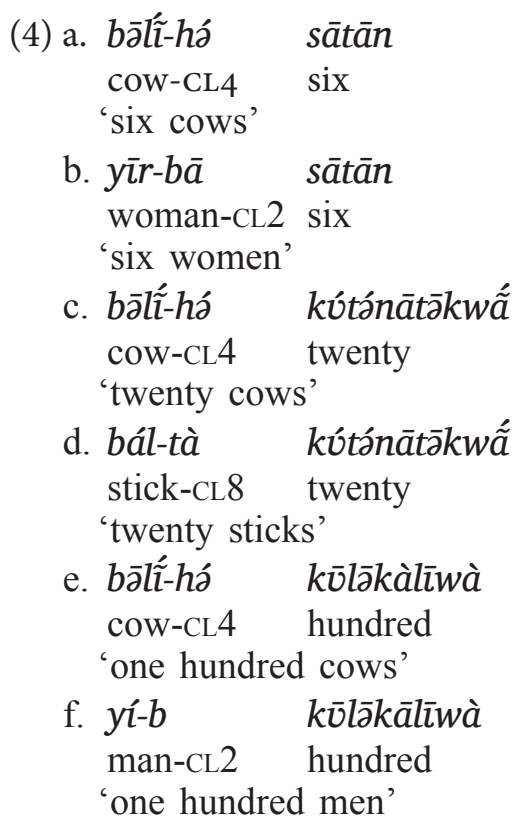

Syntactically complex numerals, such as 'eleven', 'twelve', 'twentyone' etc., are combinations of numerals that are invariable ('ten', 'twenty' etc.) and numerals that agree with the head noun ('one', 'two' etc.). Therefore, agreement marking in such complex numerals is carried out on the same elements. The numerals with 'one' (i.e. 'eleven', 
'twenty-one', 'thirty-one' etc.) agree with the singular class of the head noun. Thus, in (5a) and (5c), the noun class marker is -há while the agreement marker is -wà.

(5) a. bālî́-há kô yír kālì-wà COW-CL4 ten CON one-CL3 'eleven cows'

b. bālî́-há kô yúr ná-hà-kwấ cow-CL4 ten CON NUM-CL4-two 'twelve cows'

c. bālî́-há kútánātākwấ yúr kālì-wà cow-CL4 twenty CON one-CL3 'twenty-one cows'

If there is more than one attribute in a noun phrase including a numeral, agreement marking on the numeral is not compulsory as is the case in (6a) and (7a). In addition, the numeral marker na:- is deleted. Agreement marking on the demonstrative pronoun, in contrast, is still obligatory. If the amount is emphasized, i.e. if it is important to state that there are two and not for example three shirts, the full numeral with the numeral marker and the agreement marker must be used. Therefore, the use of nātz̄k $w \tilde{a}$ instead of $k w \tilde{u}$ (the vowel change only concerns 'two') in (6b) and nātāsár instead of sár in (7b) changes the meaning of the sentences.

(6) a. dí-tá kwî́ tĩ̄-bà shirt-CL8 two CL8-DEM 'these two shirts'

b. dí-tá nā-tā-kwã́ $\quad \overline{\tilde{a}}-b \grave{a}$ shirt-CL8 NUM-CL8-two CL8-DEM 'these Two shirts (not three)'

(7) a. dí-tá sár tĩ-bà shirt-CL8 three CL8-DEM 'these three shirts' 
b. dí-tá nā-tz̄-sár tī-bà shirt-CL8 NUM-CL8-three CL8-DEM 'these THREE shirts (not two)'

\subsubsection{Guyuk}

Agreement marking on numerals in Guyuk is less divers than in Deele. Numerals 'one' to 'seven' as well as 'nine' agree through a prefix with the noun class of the head noun.

(8) a. bālĩ-wè nà-v̀-kàl cow-CL3 NUM-CL3-one 'one cow'

b. bàlī̌lhe nà-hà-sìr cow-CL4 NUM-CL4-two 'two cows'

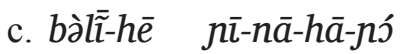
cow-CL4 four-NUM-CL4-five 'nine cows'

Numerals 'eight' as well as all decimal numerals ('ten', 'twenty', 'thirty' etc.) and 'hundred' are invariable and therefore do not agree with the head noun.

(9) a. bòlī $h \bar{e}$ jüttin cow-CL4 eight 'eight cows'

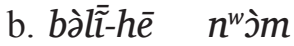
cow-CL4 ten 'ten cows'

c. bàlī̄he nātīsìr cow-CL4 twenty 'twenty cows'

d. bàlī-hē pùlèwè cow-CL4 hundred 'hundred cows' 
Syntactically complex numerals show agreement marking with the head noun on the last element of the numeral (see also §2.3) as is shown in the following examples. Those numerals ending with 'one' agree with the singular noun class of the head noun (10a).

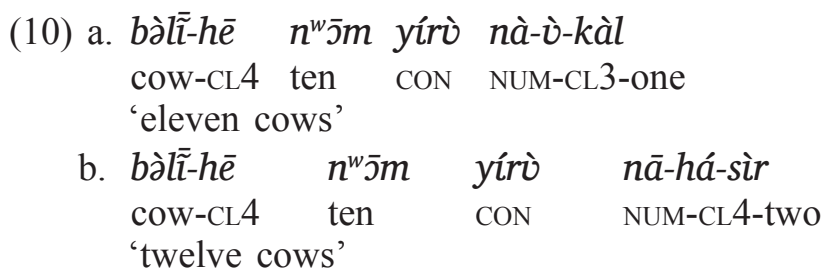

\subsubsection{Gwaanda}

Gwaanda seems to employ the same strategies as Deele: Numeral 'one' has a suffix as an agreement marker, numerals 'two' to 'five' agree with a prefix while 'six' to 'nine', 'ten', 'twenty' etc. as well as 'hundred' are invariables. ${ }^{11}$

\begin{tabular}{|c|c|}
\hline $\begin{array}{l}\text { a. gíhín } \\
\text { wife } \\
\text { 'one wife }\end{array}$ & $\begin{array}{l}\text { kàlí-yà } \\
\text { one-cL1 } \\
\text {-N3] }{ }^{12}\end{array}$ \\
\hline $\begin{array}{l}\text { b. belin-ha } \\
\text { cow-CL4 }\end{array}$ & $\begin{array}{l}\text { na-ha-tsər } \\
\text { NUM-CL4-two }\end{array}$ \\
\hline
\end{tabular}

${ }^{11}$ All examples (phrases and sentences) in Gwaanda ( $\$ 2.5$ and $\left.\S 3.3\right)$ are from texts and questionnaires written by Gwaanda mother tongue speakers. They were adopted without changes and therefore differ in their spelling from other examples. Hyphens and equal signs were added by the author for the sake of better understanding and detailed interlinearisation.

${ }^{12}$ Examples with a code in square brackets are from different unpublished sources provided to me by Ulrich Kleinewillinghöfer. S-N3 is a list with different sentences in Gwaanda. 

c. fín-thá nàkánàkwì
flower-CL8 six
'six flowers' [WL-N5] ${ }^{13}$
d. $y \grave{i}-b$
nánànyùà
man-CL2 fifty
'fifty men' (Hiraki 1986: 142)
e. dzùrnyà-hà kùlòkàlíwà
scorpion-CL4 hundred
'hundred scorpions' [WL-N5]

The data on agreement marking on syntactically complex numerals such as 'eleven', 'twelve' etc. is very sparse and ambiguous and will therefore not be presented here.

\subsection{Summary}

In $\S 2.1$ the structure of the numerals as used in counting without reference to a particular noun were examined in detail. It was shown that Longuda cardinal numerals only partially agree with Hurford's (2001: 10758) statement that numerals up to 'ten' are generally morphologically and syntactically simpler than higher numerals. Not all numerals in Longuda from 'one' to 'ten' are simple words (especially 'six', 'seven' and 'nine' in most Longuda varieties are quite complex morphologically), although the tendency to have syntactically simpler words in the first ten numerals than from 'eleven' upwards is clear.

The remaining sections dealt with the agreement strategies of numerals in a noun phrase. It became clear that cardinal numerals in a noun phrase show different strategies of agreement marking (suffixing, prefixing and invariability). The fact that the numerals for 'one' in Deele and Gwaanda, being inherently singular, behave differently than all other numerals, that are inherently plural, is not an uncommon occurrence as Zweig (2005: 11) has shown. The different agreement strategies make it difficult to place the numerals in the same lexical

${ }^{13}$ WL-N5 is a list with different phrases and sentences in Gwaanda. 
category as adjectives for example. In this regard, Longuda conforms to Corbett's (1978: 368) first universal that places numerals in-between adjectives and nouns. It should therefore be analysed as a distinct lexical category as Borchardt (2011:12) proposes. Corbett's second universal that higher numerals "will be more noun-like" (1978: 368) applies to Longuda numerals as well (compare Zweig 2005: 5ff.). Numeral 'one' in both Deele and Guyuk clearly behaves adjective-like whereas lexemes that express higher values were nominalised at an earlier stage and are now mostly invariable. Therefore, they appear to be more noun-like.

The different agreement strategies employed by numerals in a noun phrase are summarized in Table 4.

Table 4

\section{Agreement strategies of numerals in a noun phrase}

\begin{tabular}{lll}
\hline & Deele and Gwaanda & Guyuk \\
\hline $1 '$ & Suffix & Prefix \\
'2'-'5' & Prefix & Prefix \\
'6'-'7' & Invariable & Prefix \\
'8' & Invariable & Invariable \\
'9' & Invariable & Prefix \\
'10'-'100' & Invariable & Invariable \\
\hline
\end{tabular}

\section{Ordinal numerals}

Ordinal numerals "identify a referent in terms of its order with respect to other referents" (Dryer 2007: 164). They are generally classified as adjectives, being derived from cardinal numerals by morphological or syntactic means. Stolz \& Veselinova (2013) conducted a crosslinguistic survey, analysing a sample of 321 languages in regard to the morphological relation between cardinal and ordinal numerals. 
They found eight recurring patterns in languages, from non-existent ordinal numerals to regular derivation to a number of suppletive forms. Their results show that especially the lower ordinal numerals tend to be suppletive forms of the cardinal numeral counterpart, whereas higher ordinal numerals mostly derive morphologically from cardinal numerals in a regular manner (Hurford 2001: 10758; Stolz \& Veselinova 2013).

\subsection{Deele}

The ordinal numeral 'first' in Deele is a suppletive form to the cardinal numeral root 'one'. fingārā- 'first' derives from the verb fingara'a 'to begin' (see also Gwaanda).

$$
\begin{aligned}
& \text { ná-ká fíngārō-ké } \\
& \text { hand-CL7 first-CL7 } \\
& \text { 'first hand' }
\end{aligned}
$$

The ordinal numeral 'second' kúry $\bar{a}$ - is a suppletive root of the cardinal numeral root $k w \tilde{a}$ 'two'. ${ }^{14}$ It behaves like the forms for 'third' to 'fifth'. These are regularly derived from the cardinal numerals by adding a derivational suffix $-y \bar{a}$ to the stem of the numeral. They then agree with the head noun through an agreement suffix.

$$
\begin{aligned}
& \text { (13) a. ná-ká kúr-yā-ká } \\
& \text { hand-CL7 two-ORD-CL7 } \\
& \text { 'second hand' } \\
& \text { b. bālíl-wá sár-yā-wā } \\
& \text { cow-CL3 three-ORD-CL3 } \\
& \text { 'third cow' } \\
& \text { c. yïr nó-yá-yá } \\
& \text { person.Cl1 five-ORD-CL1 } \\
& \text { 'fifth person" }
\end{aligned}
$$

${ }^{14}$ They are probably etymologically related. 
All following numerals until 'ninety', in contrast, have no derivational marker $-y \bar{a}$ but do add an agreement suffix.

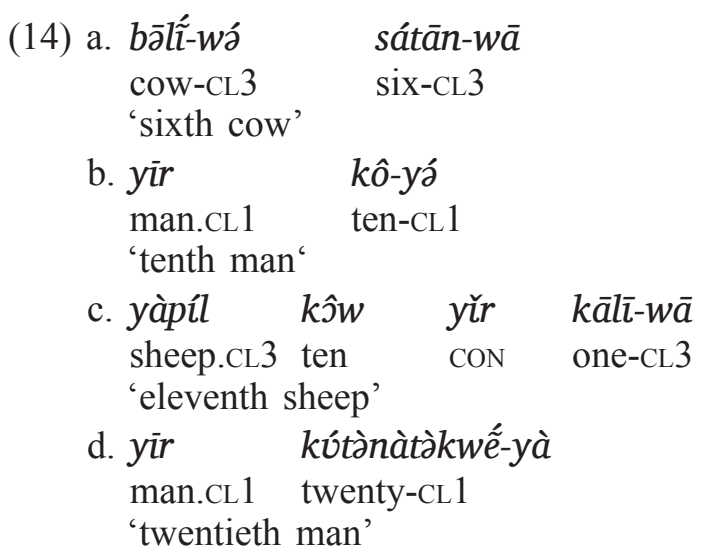

The formation of the ordinal numeral with 'hundred' was unknown to the speakers.

\subsection{Guyuk}

The form for 'first' agrees with the preceding head noun.
$z \bar{\imath}-k \bar{a} \quad k i ̀ l a ̀ v ̀-k \bar{o}$
town-CL7 first-CL7.DEF
'the first town'

All other ordinal numerals up to 'tenth' are derived by means of adding another numeral marker $n a$ - before the cardinal numeral. An agreement marker is suffixed in a noun phrase.
(16) a. $z \bar{\imath}-k \bar{a} \quad n \bar{a}-n a \bar{a} k w a \bar{a}-k \grave{\jmath}$
town-CL7 NUM-three-CL7.DEF
'the third town'
b. bālī-w nā-n $n^{w}$ óm-wò
cow-CL3 NUM-ten-CL3.DEF
'the tenth cow' 
Ordinal numerals from 'eleventh' to 'ninetieth' ('hundredth' and above was unknown to the native speakers) show no derivational marker but an agreement suffix.
a. síggīlá nwôm yír nàsìr-wò
sheep.CL3 ten CON two-CL3.DEF
'twelfth sheep'
b. síngīlá nátísìr-wò
sheep.CL3 twenty-CL3.DEF
"twentieth sheep"

In Newman (1976: 65), the lexemes for 'first, 'second', 'fifth' and 'tenth' are mentioned. These lexemes seem to have an agreement suffix -la and a clitic $=u$ marking definiteness but no second numeral marker (na-). No more information and no example sentences with a head noun they refer to are given:

nakalau 'first'

nasirlau 'second'

nanyolau 'fifth'

nwamlau 'tenth' (Newman 1976: 65)

\subsection{Gwaanda}

The ordinal numeral 'first' has the two suppletive forms káúndá- and cíngárá-. The latter derives from the verb 'to begin/start' cíngír.

(18) a. dzúín káúndá-yá=ù child.CL1 first-CL1=DEF 'the first child' (Hiraki 1986: 142)

b. yìnā jùn-là cíngárá-lá=ù COP famine-CL 5 first-CL $5=$ DEF

'this was the first famine' [B-N1] ${ }^{15}$

${ }^{15}$ B-N1 contains interviews on the history of the Longuda people and songs. 
From what the data on Gwaanda shows, ordinal numerals for 'second' and 'third' are derived from the cardinal numerals by adding a suffix -yá to the stem of the numeral which is then followed by an agreement marker.
a. yàtsa tsír-yá-wé wā-yù
visit.CL3 two-ORD-CL3 CL3-3SG.POSS
'his second visit' (Hiraki 1986: 143)
b. tsóú tsír-yá-wá =ù
house.CL3 two-ORD-CL3=DEF
'the second house' (Hiraki 1986: 142)
c. àyàbà nànyìr kúr-yá-á ín-yù
banana four three-ORD-CL6 CL6-3SG
'her third four bananas' (Hiraki 1986: 143)

There are no data available for ordinal numerals from 'fourth' to 'ninth'. Numerals from 'tenth' take the stem of the respective cardinal numeral and add either an agreement marker or an ordinal suffix. Since they are formally almost identical and no other data with different noun class agreement is available the following examples are glossed with a question mark in the meantime.
(20) a. yìr
kùwàr-yá = ù
person.CL1 ten-?=DEF
'the tenth person' (Hiraki 1986: 142)
b. gáhíng kùwàr yár nàtsár-yá=ù woman.CL1 ten CON two-?=DEF
'the twelfth woman' [WL-N5]
c. gáhíng nánàtsár-yá =ù
woman.cL1 twenty-?=DEF
'the twentieth woman' [WL-N5] 


\subsection{Summary}

As was described above, lower ordinal numerals tend to be suppletive forms while higher ordinal numerals derive regularly from cardinal numerals (Hurford 2001: 10758; Stolz \& Veselinova 2013). Longuda ordinal numerals fit into the commonest type of patterns (worldwide and across Africa) where 'first' is a suppletive form while all other numerals are regularly derived.

The numeral 'first' is a suppletive form in Deele and Gwaanda and perhaps in Guyuk, too. The other ordinal numerals are derived from cardinal numerals although the manner in which the derivation is done differs in the varieties. Deele and Gwaanda add an ordinal suffix -ya to the root of lower cardinal numerals. Guyuk prefixes another numeral marker $n a-$.

It is evident that higher ordinal numerals tend to not be derived by any markers but simply by adding the respective agreement suffix. This means that, just as with the cardinal numerals, there is a split in formation of the ordinal numerals. The results are summarized in Table 5 .

Table 5

Formation of cardinal numerals and their agreement strategies in a noun phrase

\begin{tabular}{|c|c|c|c|}
\hline & Deele & Guyuk & Gwaanda \\
\hline ' 1 st' & suppletive-AGR & 1-AGR & suppletive-AGR $(=\mathrm{DEF})$ \\
\hline ' $2^{\text {nd }}$, & suppletive-ORD-AGR & NUM-2-AGR(.DEF) & 2-ORD-AGR $(=\mathrm{DEF})$ \\
\hline ' $3^{\text {rd }}$ & 3-ORD-AGR & NUM-3-AGR(.DEF) & 3 -ORD-AGR $(=\mathrm{DEF})$ \\
\hline ' $4^{\text {th }}-5^{\text {th }}$, & 4-ORD-AGR & NUM-4-AGR(.DEF) & \\
\hline ' $6^{\text {th }-9^{\text {th }}}$ & 6-AGR & NUM-6-AGR(.DEF) & \\
\hline ' $10^{\text {th }}$, & $10-\mathrm{AGR}$ & NUM-10-AGR(.DEF) & 10-ORD/AGR? $(=\mathrm{DEF})$ \\
\hline ' $11^{\text {th }}-99^{\text {th }}$, & 11-AGR & 11-AGR(.DEF) & 11-ORD/AGR? $(=\mathrm{DEF})$ \\
\hline
\end{tabular}




\section{Comparison to other Adamawa languages}

Since numerals in Adamawa languages are quite heterogeneous, it is difficult to compare them with each other or reconstruct proto forms. Nevertheless, Pozdniakov (2018) as well as Boyd (1989) have made attempts to reconstruct Adamawa numerals and in the following a few of their remarks will be compared to Longuda.

In most Adamawa languages numeral 'six' is a compound of 'five' plus 'one' (Pozdniakov 2018: 164). Longuda has two forms in the different varieties, both of which are different from the 'five' plus 'one' pattern. Instead, they use numeral 'three' as a base. As stated above, sāitān of Deele is probably a compound of the numeral 'three' and a yet unknown other element. Pozdniakov (ibid.), in contrast, suggests it may go back to the Chadian Arabic word for 'six' sitee.

Pozdniakov (2018: 167) states that “a primary term for 'nine' was apparently non-existent in Proto-Adamawa". Common patterns are 'five' plus 'four' or 'ten' minus 'one'. Deele has the common 'five' plus 'four' pattern but Guyuk has it the other way around: 'four' plus 'five'. According to Boyd (1989: 167) a compound of 'four' plus 'five' is only present if numeral 'eight' is not a compound. Since 'eight' nitin is suspected to be a compound of 'four' and an unknown element, Guyuk seems to be an exception of Boyd's claim.

Finally, as has been stated above, the lexeme for 'ten' koo, kô or kūr in Kola, Deele and Gwaanda respectively, fit into the reconstructed form of Adamawa languages for 'ten' *kob (Pozdniakov 2018: 168). Boyd (1989: 168) comes to the same conclusion for a subgroup of Adamawa languages but hints towards the lexeme gomà for 'ten' in Hausa. It seems like he suggests gomà to be the original source of *kob. If this is true, gûm in Guyuk and Cerin has the same origin as the lexemes in Kola, Deele and Gwaanda have. However, as was suggested above, a borrowing from the Dera word for 'ten' gûm is more likely.

According to Pozdniakov (2018: 15),

"[i]n the majority of Niger-Congo languages while naming a numeral (for example, in counting) noun class markers are used. These markers 
may be the same for all numerals, but this is a rare case. More often, for the numerals 1-10 there are three to four different markers (furthermore, special class markers may be used for the numerals ' 20 ', ' 100 ', ' 200 ' and others)".

Interestingly, some Adamawa languages with a noun class system, such as the neighbouring language Waja or the nearby subgroup BənaMboi, do not or hardly employ noun classes on numerals in normal counting (Kleinewillinghöfer 2014b; 2014c; p.c.). Longuda is such a case, too, with one exception, i.e. numeral 'one' in Deele and Gwaanda: kâlì-wá and kàlí-lā respectively. The noun classes with numeral 'one' in Deele and Gwaanda conform to a general Niger-Congo pattern that Pozdniakov (2018: 16f.) describes:

"Some numerals [...] tend to be marked with a specific noun class, thus standing in opposition to the rest of the numerical terms. The use of this specific class is especially frequent with the terms for 'one', 'hundred' and "thousand"'.

Another common strategy in Niger-Congo languages are analogical changes in numerals. Analogical change is "the formal alignment of numbers resulting from the diachronic alignment of forms by analogy" (Pozdniakov 2018: 37). It involves "irregular phonetic changes in lexical stems" and results in "similar forms" in "contiguous numerals" (ibid.). However, these forms "are not always easily distinguishable from phonetic similarities conditioned by morphological changes" (ibid.). This latter point applies to the many numeral lexemes in Longuda that start with the morpheme nas-. It probably originates, as stated above, from either the root of naka 'hand' or niya 'thing', forming a compound with the root of the numeral. Without this knowledge it would seem as if Longuda employs a wide-spread analogical change from numerals 'one' to 'six' (with exceptions in some varieties, see Table 2).

Still, Longuda seems to have at least one analogical change it shares with many other Adamawa as well as Kwa languages. While these languages often have an initial $n$ - with the numerals 'four' and 'five' all 
five Longuda varieties have the alveolar nasal $n$ - as an onset of the numeral root (nur 'four' and $n \mathcal{0}$ 'five'). In addition, in many of these aforementioned languages numeral 'three' starts with an $s$ - or $t$-. This is in accord with the forms for 'three' in Kola and Deele (-tsár and -sár, respectively). Together with the reconstructed form *taat for 'three' in Adamawa languages (Pozdniakov 2018: 160) and its analogy to the Bantu reconstruction *tátò and its variants such as sas and rar (ibid. 261ff.) it leads me to the conclusion that the forms for 'three' in Kola and Deele are the original forms while the other varieties, Gwaanda, Guyuk and Cerin, have swapped their numerals 'two' and 'three'.

\section{Conclusion}

Pozdniakov's (2018: 146) statement that Adamawa languages are very divers, especially in the numeral system, applies not only to Adamawa languages in general but also to Longuda in particular. The three varieties examined here, Deele, Guyuk and Gwaanda, have many similarities that clearly show a very close genetic relationship, while there are also apparent differences in the structure and behaviour of numerals. "Numeral systems are language specific, even among closely related languages [and varieties, in some respect] numeral systems might differ considerably in their internal structure" (Borchardt 2011: 22). Still, there are some patterns and characteristics that can repeatedly be found in Adamawa languages (e.g. the pattern 'five' plus 'one' for 'six'), whereas Longuda often stands out in this respect in regard to neighbouring and related noun class languages.

However, generally speaking, Longuda conforms to most numerals of the world's languages in that (a) lower numerals are less (syntactically) complex than higher ones, (b) numerals are neither all adjectives nor all nouns but rather fall in-between those categories. It can be said that (c) lower numerals lean towards being more adjective-like while higher numerals are more noun-like. Concerning ordinal numerals, (d) they show the tendency to be derived from the respective cardinal numeral whereas (e) the lexeme for 'first' is often a suppletive form. 


\section{Acknowledgements}

I would like to express my gratitude to the Longuda speakers I was honoured to work with, especially Enoch Gumnini Melton, Gayus Gulkawi and Ezekiel Benson Galangu, who have patiently answered my many questions and have given me an insight into their beautiful language. Many thanks also to the Dr. Elisabeth Grohs foundation as well as to all the members of the Department of Linguistics and Translation of the Theological College of Northern Nigeria who made the research on Longuda possible and my stays in Bukuru very pleasant. I would also like to thank Ulrich Kleinewillinghöfer who has entrusted me with manuscripts of Longuda (Gwaanda) folktales, songs and historical narrations as well as numerous wordlists that he collected in the early 1990s in Nigeria. They are an invaluable addition to my own research. I am grateful to him as well as to Raimund Kastenholz, Sabine Littig, Klaus Beyer and two anonymous reviewers for numerous helpful comments on different versions of this paper.

\section{Abbreviations}

$\mathrm{CL}-$ noun class $\quad \mathrm{DEM}-$ demonstrative $\quad \mathrm{NUM}$ - numeral marker

CON - connector NOM - nominalisation $\quad$ p.c. - personal communication

\section{References}

Blench, Roger. 2013. The Adamawa languages. https://www. rogerblench.info/Language/Niger-Congo/AU/Adamawa\%20language $\% 20$ list.pdf (Accessed 2019-11-08.)

Borchardt, Nadine. 2011. A morphosyntactic categorization of Ikaan numerals. In Kramer, Raija \& Tröbs, Holger \& Kastenholz, Raimund (eds.), Afrikanische Sprachen im Fokus: Linguistische Beiträge zum 19. Afrikanistentag, Mainz, 8.-10. April 2010, 9-26. Cologne: Rüdiger Köppe Verlag.

Boyd, Raymond. 1989. Number systems in the Adamawa branch of NigerCongo. African Languages and Cultures 2. 149-173.

Chan, Eugene. 2020. Numeral systems of the world's languages. https://mpilingweb.shh.mpg.de/numeral/ (Accessed 2020-01-07.) 
Comrie, Bernard. 2013. Numeral bases. In Dryer, Matthew S. \& Haspelmath, Martin (eds.), The world atlas of language structures online. https:// wals.info/chapter/131 (Accessed 2019-12-05.)

Corbett, Greville G. 1978. Universals in the syntax of cardinal numerals. Lingua 46. 355-368.

Dryer, Matthew S. 2013. Order of Numeral and Noun. In Dryer, Matthew S. \& Haspelmath, Martin (ed.), The world atlas of language structures online. https://wals.info/chapter/89 (Accessed 2019-12-03.)

Dryer, Matthew S. 2007. Noun phrase structure. In Shopen, Timothy (ed.), Language typology and syntactic description. Vol. 2. Complex constructions, 151-205. Cambridge: Cambridge University Press.

Elstermann, Julius-Maximilian \& Fiedler, Ines \& Güldemann, Tom. 2019. Toward reconstructing noun classification in Longuda. (Paper presented at Adamawa Conference, Mainz, 9-11 September 2019.)

Epps, Patience. 2006. Growing a numeral system: The historical development of numerals in an Amazonian language family. Diachronica 23(2). 259-288.

Greenberg, Joseph H. 1963. The languages of Africa. Bloomington: Indiana University.

Güldemann, Tom \& Fiedler, Ines. 2019. Niger-Congo "noun classes" conflate gender with deriflection. In Di Garbo, Francesca \& Olsson, Bruno \& Wälchli, Bernhard (eds.), Grammatical gender and linguistic complexity. Vol. 1. General issues and specific studies, 95-145. Berlin: Language Science Press.

Hiraki, Francis T. 1986. Noun-phrases of languages in contact: A case study of English and Nungura. Its implication for curriculum development in Nigeria. Jos: University of Jos. (M.A. thesis.)

Hurford, Jim. 2001. Numeral systems. In Smelser, Neil J. \& Baltes, Paul B. (eds.), International encyclopedia of the social and behavioral sciences, 10756-10761. Amsterdam: Pergamon Press.

Hurford, Jim. 1994. Typology of numeral-noun interaction. Proceedings of the Edinburgh Linguistics Department Conference, 26 and 27 May 1994, 33-40. Edinburgh.

Kleinewillinghöfer, Ulrich. 1994. Vokal Harmonie im Longuda. (Paper presented at 11. Afrikanistentag, Cologne, 19-21 September 1994.) 
Kleinewillinghöfer, Ulrich. 1996. Die nordwestlichen Adamawa-Sprachen: Eine Übersicht. In Seibert, Uwe (ed.), Afrikanische Sprachen zwischen Gestern und Morgen: Beiträge zur Dokumentation, Klassifikation und Rekonstruktion, 80-103. Cologne: Rüdiger Köppe Verlag. (Frankfurter Afrikanistische Blätter 8.)

Kleinewillinghöfer, Ulrich. 2014a. Longuda (Nungura) cluster: Pronouns and numbers 1-10. https://www.blogs.uni-mainz.de/fb07-adamawa/ files/2014/03/Longuda-pronouns-and-numbers-1-10.pdf (Accessed 2019-11-08.)

Kleinewillinghöfer, Ulrich. 2014b. Tula - Waja group: Pronouns and numbers 1-10. https://www.blogs.uni-mainz.de/fb07-adamawa/files/ 2014/03/Tula-Waja-Pronouns-and-Numbers.pdf (Accessed 2019-1218.)

Kleinewillinghöfer, Ulrich. 2014c. Bikwin-Jen: Pronouns and numbers 1-10. https://www.blogs.uni-mainz.de/fb07-adamawa/files/2014/03/ Bikwin-Jen-Pronouns-and-Numbers-1-10.pdf (Accessed 2019-12-18.)

Kleinewillinghöfer, Ulrich. 2020. Adamawa. In Vossen, Rainer \& Dimmendaal, Gerrit J. (eds.), Handbook of African languages, 219-230. Oxford: Oxford University Press.

Kraft, Charles H. 1981. Chadic wordlists. Vol.1 Plateau-Sahel. Berlin: Dietrich Reimer. (Marburger Studien zur Afrika- und Asienkunde 23.)

Newman, John \& Newman, Bonnie. 1977. Longuda dialect survey. Dallas: SIL.

Newman, Bonnie. 1976. Deep and surface structure of the Longuda clause. Linguistics 14(171). 35-68.

Pozdniakov, Konstantin. 2018. The numeral system of Proto-Niger-Congo: A step-by-step reconstruction. Berlin: Language Science Press.

Sabe, Charles Z. 2014. The people of Nyuwar. Zaria: Tamaza.

Stolz, Thomas \& Veselinova, Ljuba N. 2013. Ordinal numbers. In Dryer, Matthew S. \& Haspelmath, Martin (eds.), The world atlas of language structures online. https://wals.info/chapter/53 (Accessed 2019-11-13.)

Zweig, Eytan. 2005. Nouns and adjectives in numeral NPs. ProceedingsNELS 35, 2. 663-676.

Received 13.01.2020. Received in revised form 09.06.2020. Accepted 04.08.2020 